\title{
Administration and Interpretation of PPD Test
}

\author{
PPD Testi Uygulaması ve Yorumu
}

\author{
Bengisu Menentoğlu'(iD), Ceren Şimşek'(iD), Nevin Hatipoğlu'(iD) \\ ${ }^{1}$ Clinic of Pediatrics, SBU Bakırkoy Dr Sadi Konuk Training and Research Hospital, Istanbul, Turkey
}

Cite this article as: Menentoğlu B, Şimşek C, Hatipoğlu N. Administration and interpretation of PPD test. J Pediatr Inf 2021;15(1):e52-e57.

\section{Introduction and General Information}

Tuberculosis (TB) is a devastating infectious disease caused by Mycobacterium tuberculosis and most frequently affects the lungs. In children, direct detection of the organism in diagnosis is challenging and at a low rate. Therefore, tests depending on the host's response to the infection is important in the diagnosis of tuberculosis in children. Two screening tests are used in the diagnosis of TB: 1-Tuberculin skin test (TST), 2- Interferon-gamma release test (IGRT).

The oldest tuberculosis screening test most widely used in the diagnosis of tuberculosis is the practice of intracutaneous injection of purified protein derivative (PPD) known as tuberculin. PPD contains antigenic components isolated through protein precipitation from tuberculosis bacilli culture filter. PPD-S is accepted as the international standard, and PPDs produced equivalently are used for tests.

TST is a method showing the cellular immune response of a previously infected individual with $M$. tuberculosis. TST does not differentiate latent infection from active tuberculosis disease and is used more to evaluate the presence of latent TB infection. Principally, it is used for the contact screening of people in close contact with tuberculosis. In addition, it is used as part of tests targeted at high risk groups for TB such as healthcare workers working in high risk areas for TB and residents and employees of penitentiaries.
The most reliable method in the administration of tuberculin test is the intracutaneous test known as "Mantoux". It should be done and read by a physician or a healthcare worker trained in the procedure at a healthcare center with appropriate equipment.

\section{Equipment required for the procedure (Figure 1)}

- Well-lit table and chair

- Refrigerator with automated temperature monitorimng system

- PPD solution

- $\quad$ Single use syringe with a thickness of 27 gauge and 1 $\mathrm{mL}$ measurement divisions.

- Disposal cup for sharp medical objects resistant to puncture

- A transparent ruler with millimeters

- Ball-point pen

- Gloves

- Gauze, cotton

- Patient form and PPD result card to record the result

\section{Pre-procedure Preparation}

PPD test can be administered to outpatients and inpatients. The family and the child are informed on the procedure, and consent is received. It should be expalined to the

\footnotetext{
Correspondence Address / Yazışma Adresi

Nevin Hatipoğlu

SBÜ Bakırköy Dr. Sadi Konuk Eğitim ve Araştırma Hastanesi,

Çocuk Sağlığı ve Hastalıkları Kliniği,

İstanbul-Türkiye

E-mail: naydin9@mynet.com
}

Received: 04.02 .2021

Accepted: 23.02.2021

Available Online Date: 02.04 .2021

@Copyright 2021 by Pediatric Infectious Diseases and Immunization Society. Available online at www.cocukenfeksiyon.org 


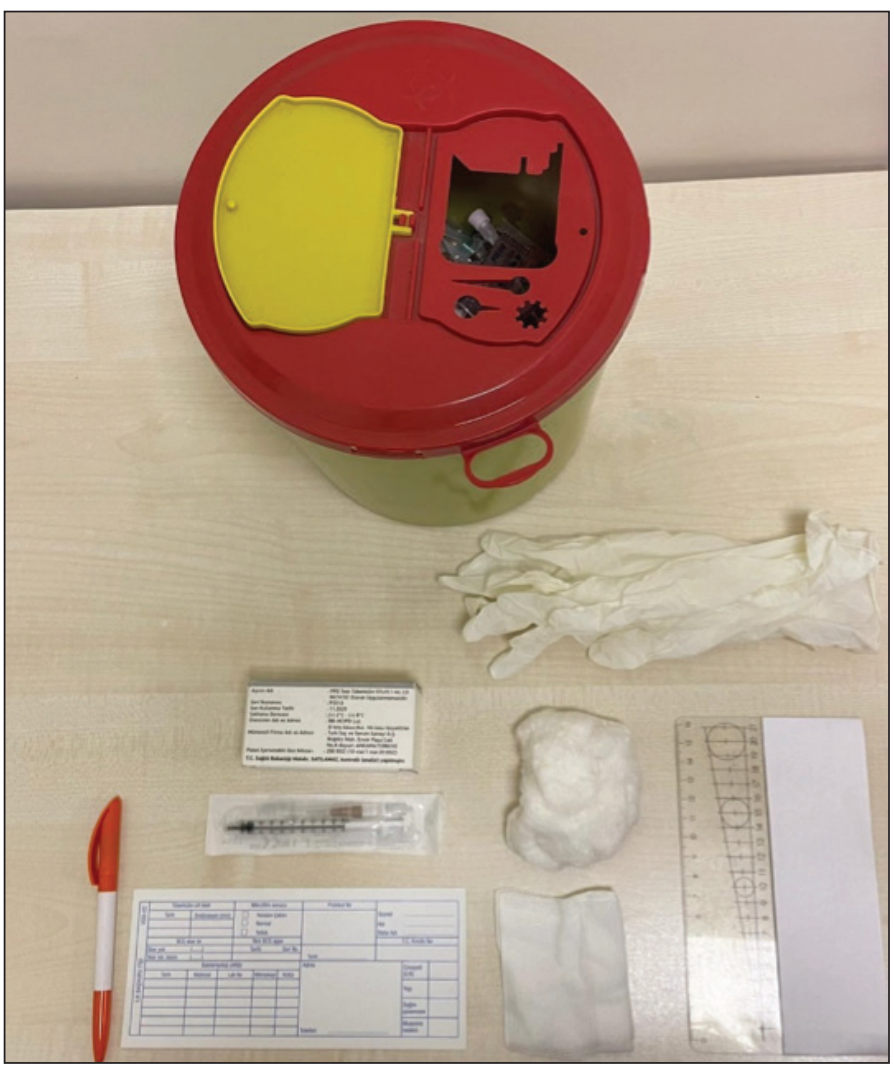

Figure 1. Equipment used during PPD test.

family that the procedure will not take long but the child will feel pain for a short period of time on his/her arm. It is preferably administered into the inner surface of the left forearm far from veins and without scar tissue, irritation and open wound. The forearm is placed on a well-lit, fixed and plain surface with the palm facing upward. During the procedure, th elbow of the patient should be slightly bent and held steady without moving the arm. If both arms cannot be used for the test, it can be administered at the back of the shoulder.

PPD solution must be preserved in a light-proof brown glass bottle (Figure 2), and when not used, it must be kept in a refrigerator at +2 and $+8^{\circ} \mathrm{C}$ with automated monitoring of the temperature (Figure 3). Once opened, the PPD solution can be used for 1 month, and bottles exceeding this duration must be disposed of. It should not be allowed for syringes filled with PPD solution to be used after the $20^{\text {th }}$ minute, and the unused full synrignes must be disposed after 20 minutes. Exposure to room temperature and light can make the skin test antigen less effective. If the syringes have been filled previously and the liquid containing tuberculin is kept in the syringe, the proteins can sti$\mathrm{ck}$ to the wall of the syringe and make the test ineffective.

The test is not performed in cases that show severe systemic allergic reaction and anaphylactic shock or in cases of blisters, ulcerations and necrosis formation on the administration area.

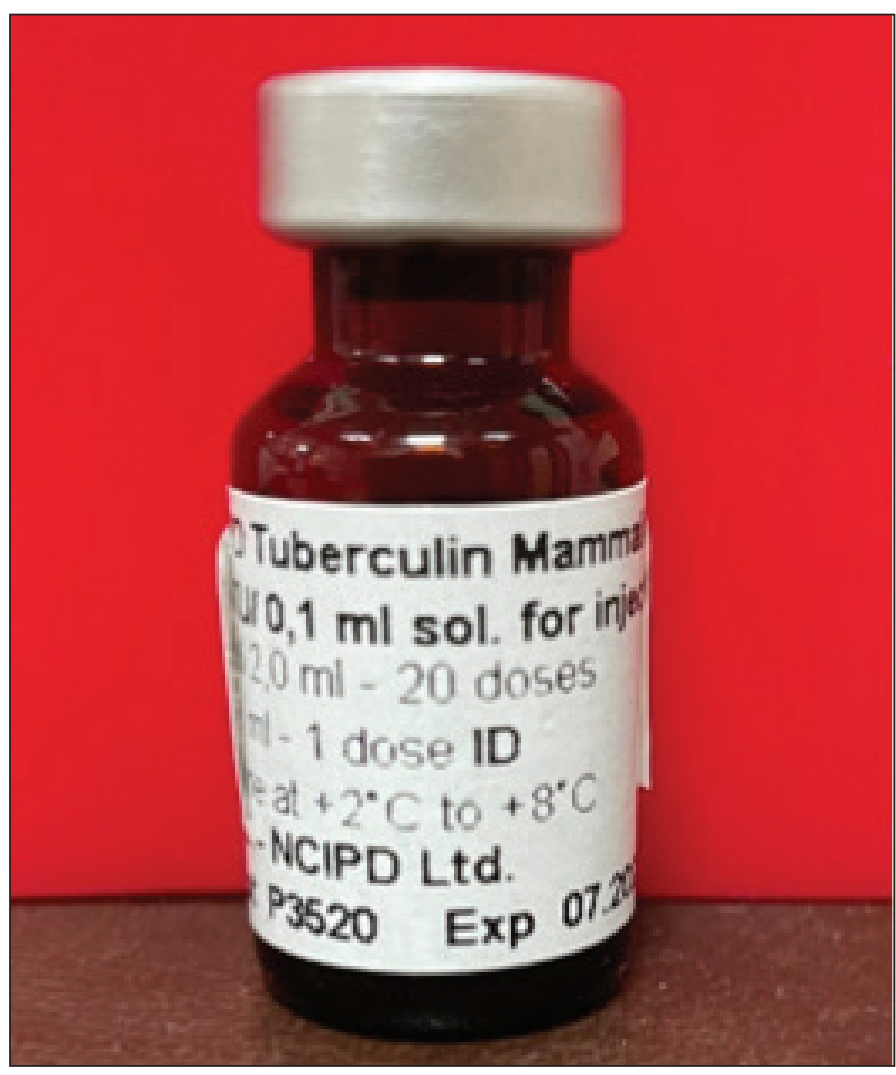

Figure 2. PPD solution must be kept in a brown light-proof glass bottle.

\section{The procedure (Figure 4)}

PPD test is a two-phase procedure, and the patient must be in the healthcare institution for both procedures:

First Phase (PPD administration): The test is administered to the patients by a trained healthcare worker.

Second Phase (PPD reading): After a specific period of time (at the $48^{\text {th }}$ or $72^{\text {nd }}$ hour), the change on the skin of the test area is evaluated.

Prior to drawing the PPD solution, which is kept in the refrigerator when not used, to the injection syringe, the vial is wiped by an alcohol-soaked cotton. $0.1 \mathrm{~mL}$ of the solution is drawn into the injection syringe with a needle of 27 gauge thickness. In order to guarantee the right volume, more than a one-tenth of 1 milliliter is drawn into the injection syringe, and the needle is taken out of the bottle. While the syringe is held at an upright position, the piston is slightly retracted, the syringe is slightly hit to gather all air bubbles and pushed forward. This way, the air bubbles and the extra liquid in the syringe is drawn out, and exactly one-tenth of the tuberculin solution is left in the syringe.

The skin area to be used for tuberculin administration is not wiped with any antiseptics. The administrator holds the skin between the thumb and index finger tight so as to provide better and easier penetration of the needle into the skin. 


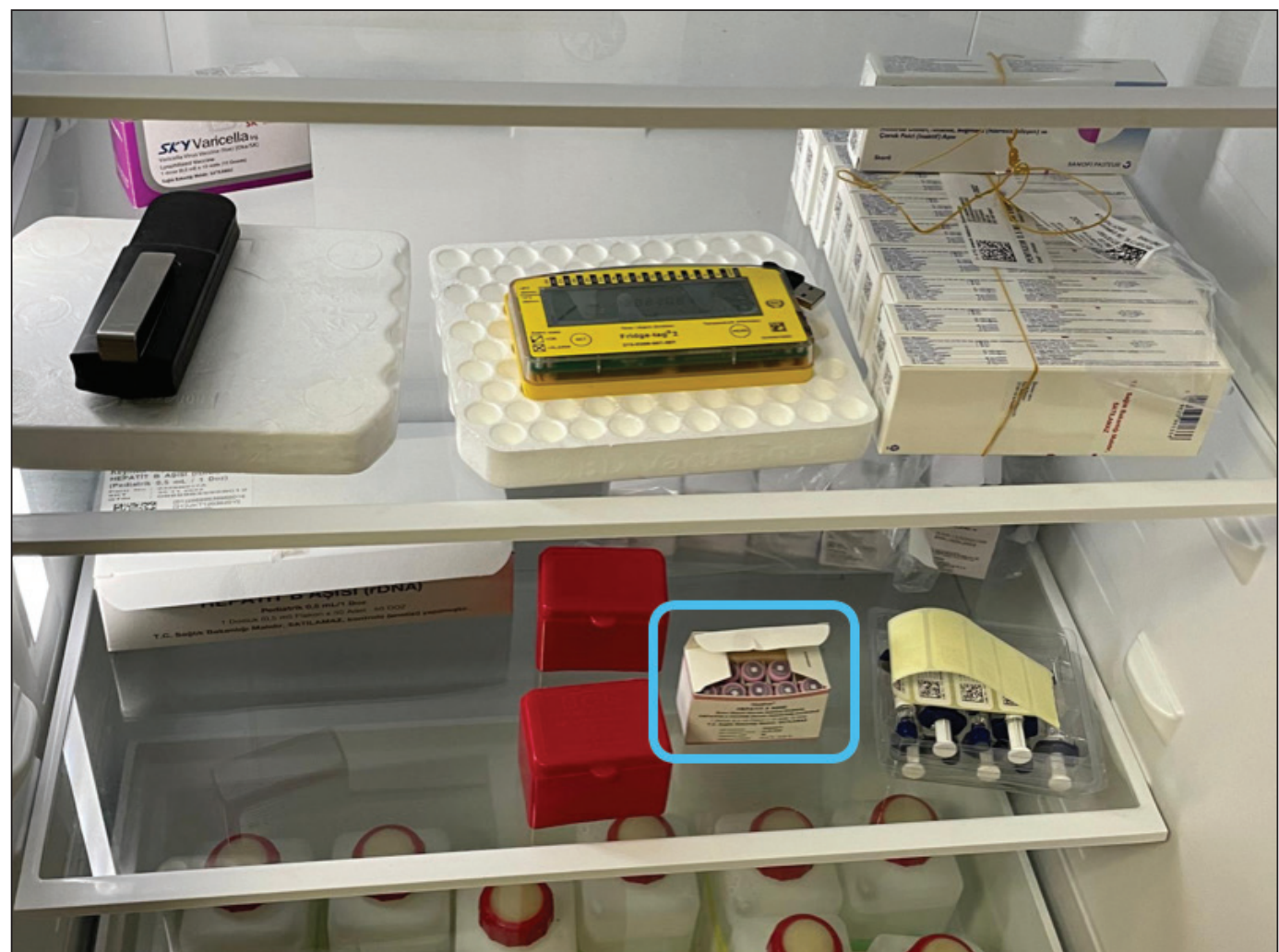

Figure 3. PPD solution (marked in blue frame) must be kept in a refrigerator whose temperature is monitored (between +2 and $+8^{\circ} \mathrm{C}$ ).

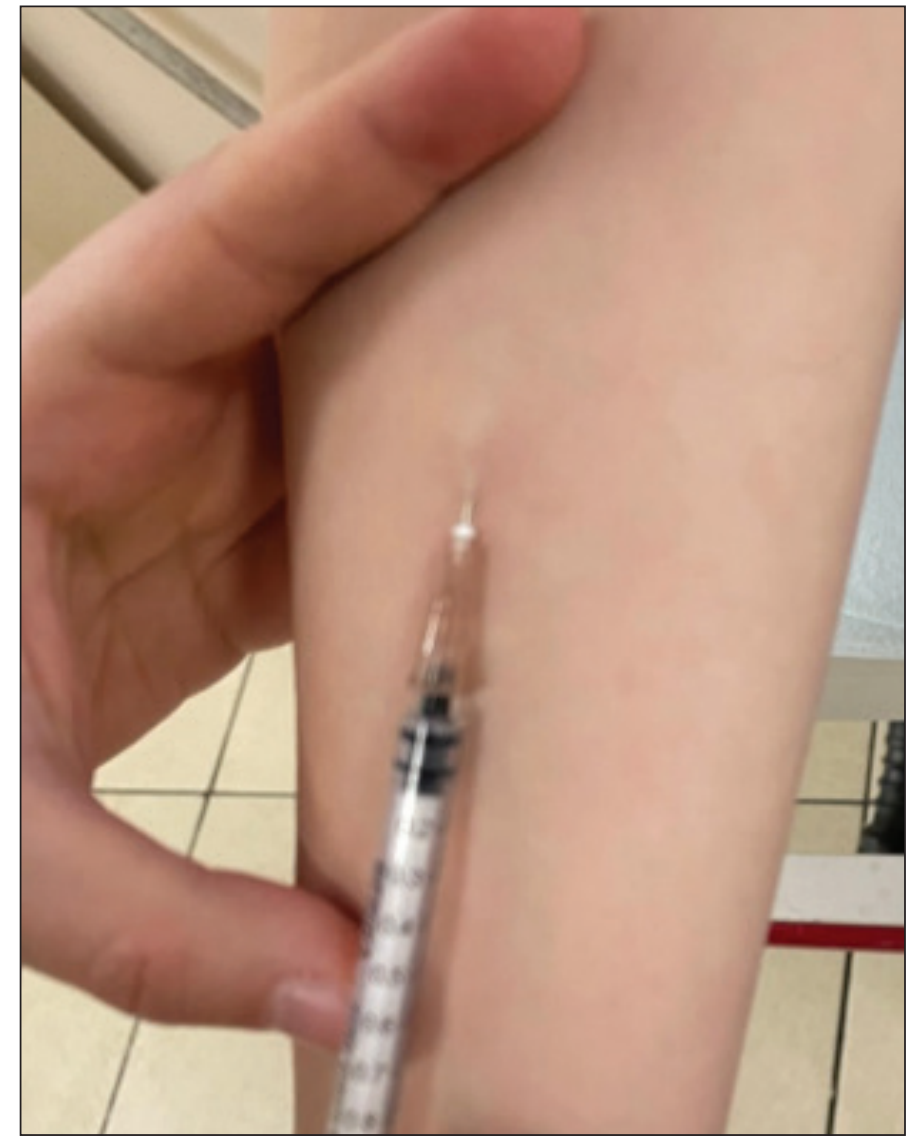

Figure 4. Intradermal administration technique of the PPD test.
The needle tip is penetrated into the skin held at $5-15^{\circ}$ with the needle bevel facing upward. The needle tip is pressed forward for $3 \mathrm{~mm}$, and the obliquity of the needle should be seen right under the skin. A rather hard resistance will be felt once the tuberculin is injected into the skin. Upon injecting the solution intracutaneously, a wheal 6 to $10 \mathrm{~mm}$ in diameter should be produced on the injection area. The needle is withdrawn without massaging or pressing the site. Afterwar$\mathrm{ds}$, the used syringe must be immediately disposed of in the specified cup resistant to puncture. It is not unusual to have a drop of blood on the injection site even if the needle is placed correctly. In this case, the blood is softly wiped with a gauze or cotton.

There is no need to wrap the area with a special bandage. It should be explained that there might be slight itchiness and swelling and these are all normal reactions that do not require treatment and will heal in a week. The patient should be told not to scratch the area, to keep it clean and dry and not to put cream, lotion or sticky bandage on it. Moreover, it should also be noted that bathing the area with water is not harmful but it should not be scratched or rubbed.

Allergic reaction can be seen with tuberculin, and adrenaline must be kept available during the procedure.

If the PPD skin test could not be done technically correct, a second test dosage can be administered at least $5 \mathrm{~cm}$ away 


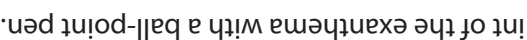

·рәләр!suos әq оsје p!nous uo!!

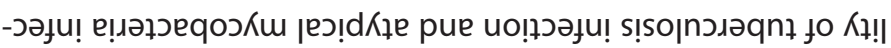

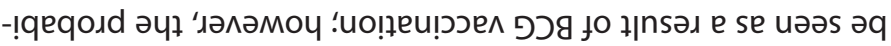
ueว uо!

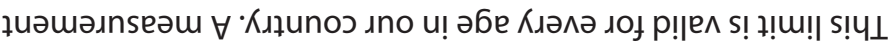

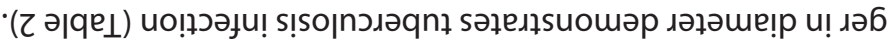

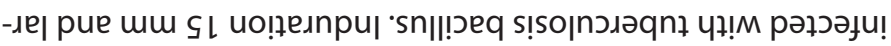

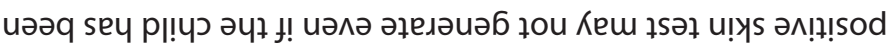

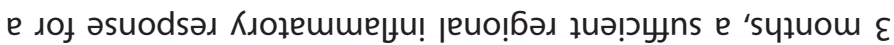

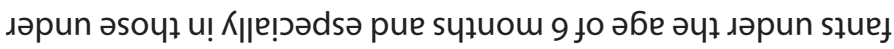

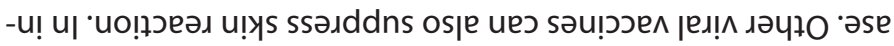

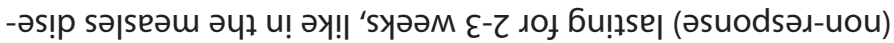

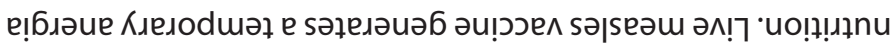

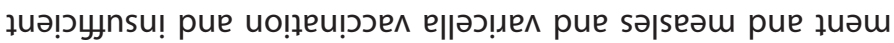
-ןеәд ұ

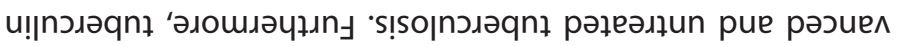

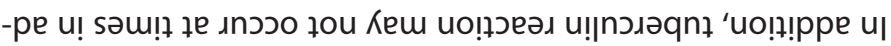

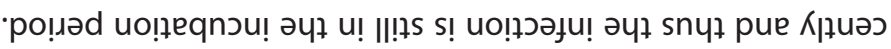

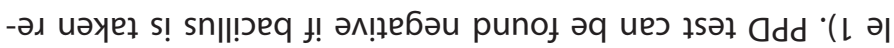

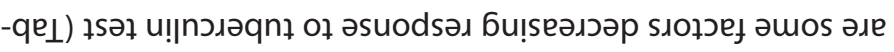

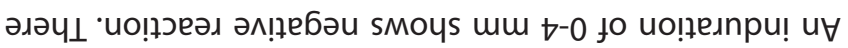

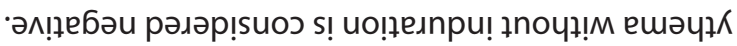

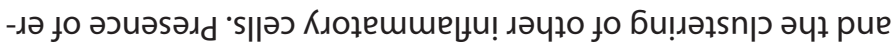

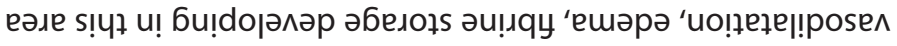

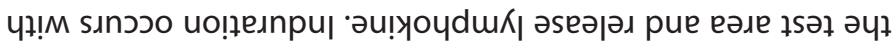

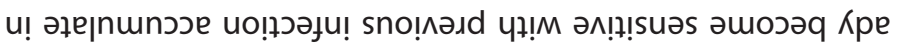

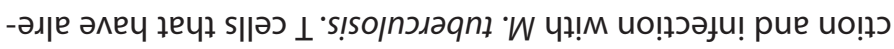
-еәл Кұ!

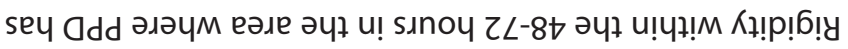

'

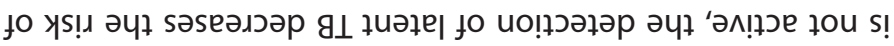

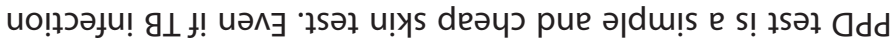

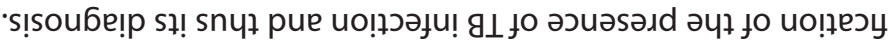

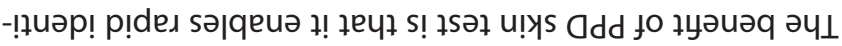

uo!ssnวs!a

-uo!̣exzs!u!upe fo

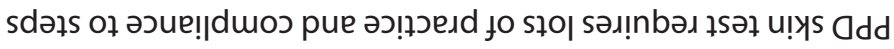

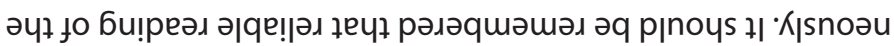

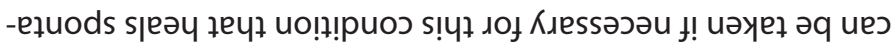

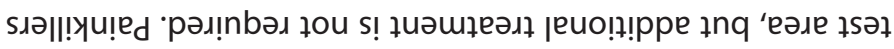

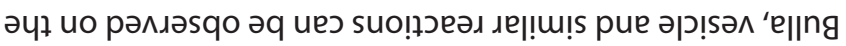

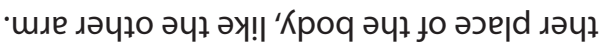

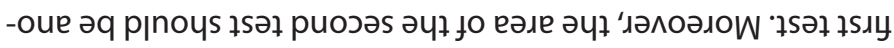

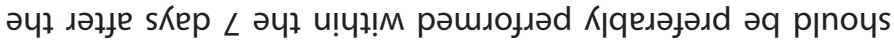

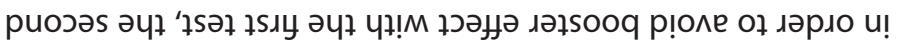

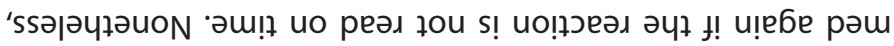

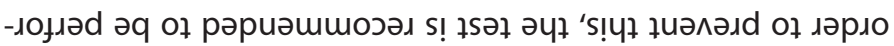

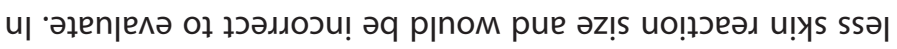

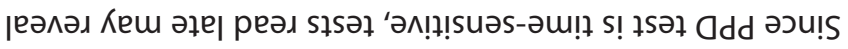

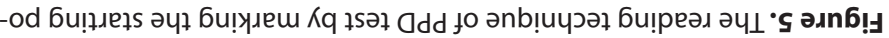

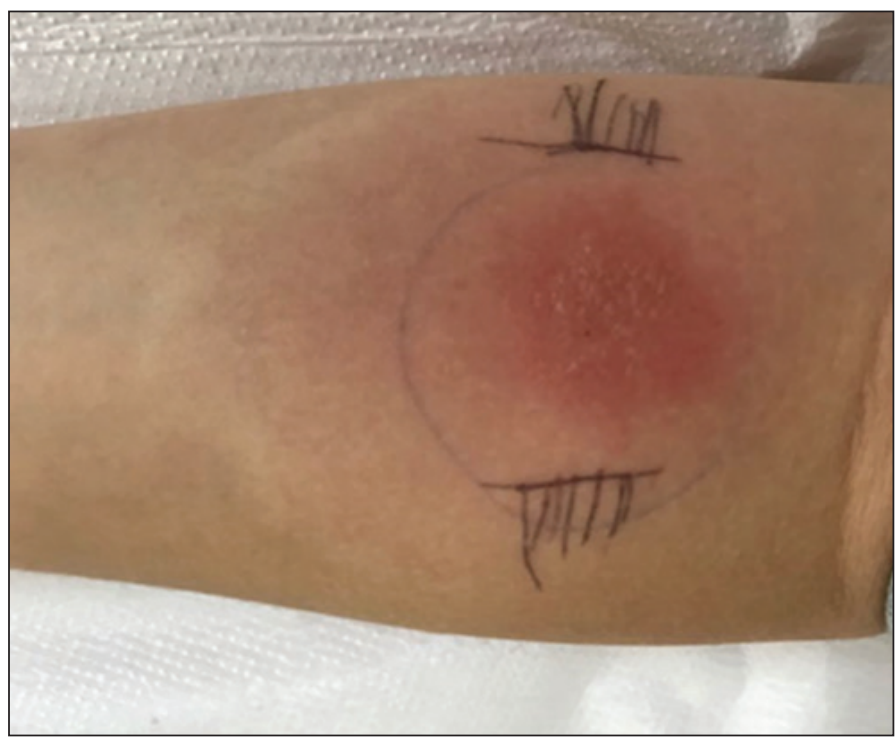

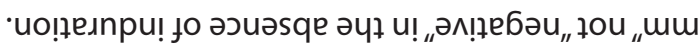

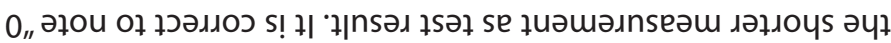

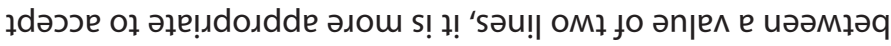

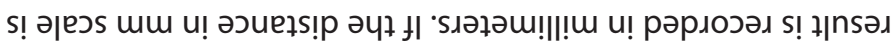

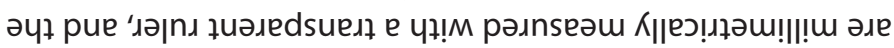

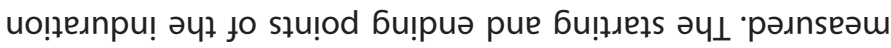

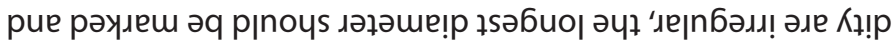

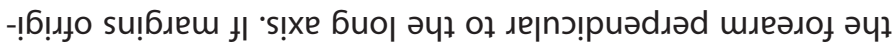

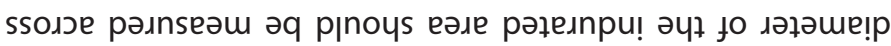

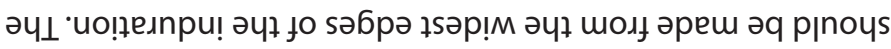

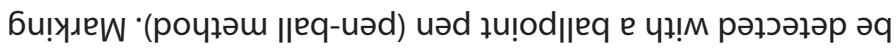
ueว uo!ıeגnpu! fo u!̣!ı fo słu!

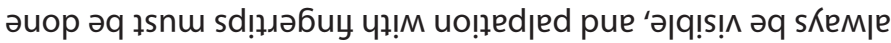

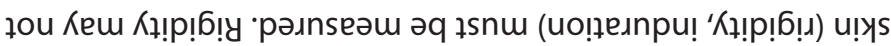

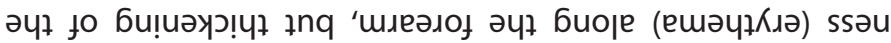

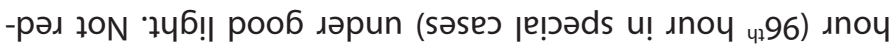

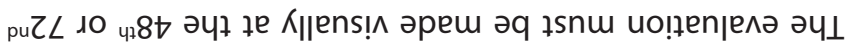

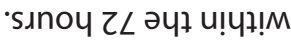

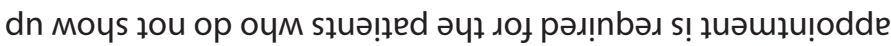

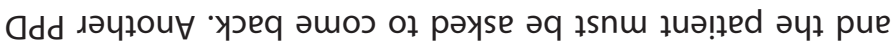

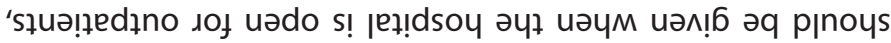

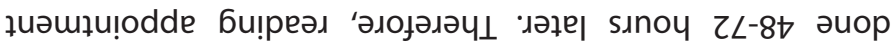

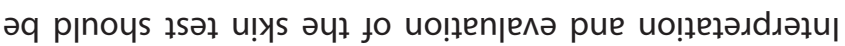

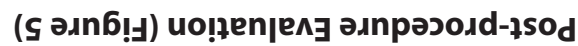

Кर!

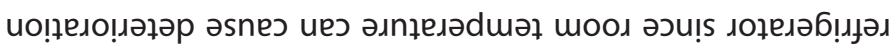

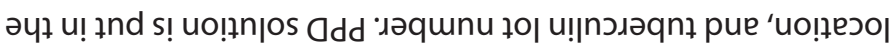

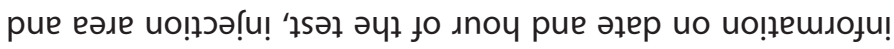

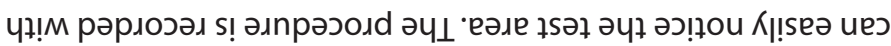

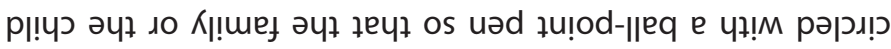

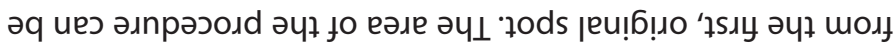


Table 1. Factors decreasing response to tuberculin test

\begin{tabular}{|c|c|}
\hline Factor & Disease or Condition \\
\hline Factors related to the individual being tested & $\begin{array}{ll}\text { - } & \text { Infections } \\
& \text { - } \quad \text { Viral (measles, mumps, varicella, HIV) } \\
& \text { - } \quad \text { Bacteria (typhoid, typhus, brucella, pertussis, prevalent TB, TB pleurisy) } \\
\text { - } & \text { Live virus vaccines (measles, mumps, polio, varicella) } \\
\text { - } & \text { Metabolic disorders (chronic renal deficiency) } \\
\text { - } & \text { Low proteins (serious low protein levels, afibrinogenemia) } \\
\text { - } & \text { Diseases affecting lymphoid organs (Hodgkin's disease, lymphoma, chronic leukemia, sarcoidosis) } \\
\text { - } & \text { Drugs (corticosteroids and many other immunosuppresseant drugs) } \\
\text { - } & \text { Age (newborns, elderly patients with "decreased" sensitivity) } \\
\text { - } & \text { Stress (surical, burns, mental diseases, graft versus host reactions) }\end{array}$ \\
\hline Factors related to the tuberculin used & $\begin{array}{ll}\text { - } & \text { Inappropriate storage (exposure to light and heat) } \\
\text { - } & \text { Inappropriate dilution } \\
\text { - } & \text { Chemical denaturation } \\
\text { - } & \text { Ahesion (partially controlled adding Tween } 80 \text { ) }\end{array}$ \\
\hline Factors related to method of administration & $\begin{array}{ll}\text { - } & \text { Injecting vewy few antigens } \\
\text { - } & \text { Suncutaneous injection } \\
\text { - } & \text { Late administration after drawing to the injector } \\
\end{array}$ \\
\hline Factors related to reading and evaluation & $\begin{array}{ll}\text { - } & \text { Inexperienced reader } \\
\text { - } & \text { Conscious or unconcious mistakes } \\
\text { - } & \text { Mistakes in records }\end{array}$ \\
\hline
\end{tabular}

Table 2. Evaluation criteria of tuberculin skin test (TST) in our country.

\begin{tabular}{|c|c|c|}
\hline BCG Vaccination Status & Induration Diameter & Interpretation \\
\hline \multirow[t]{3}{*}{ In patients with BCG vaccination } & $0-5 \mathrm{~mm}^{*}$ & Accepted negative. \\
\hline & $6-14 \mathrm{~mm}^{*}$ & Could be related to BCG vaccination or non-tuberculous mycobacteria \\
\hline & $15 \mathrm{~mm}$ and over & Accepted positive. \\
\hline \multirow[t]{3}{*}{ In patients without BCG vaccination } & $0-5 \mathrm{~mm}^{*}$ & Accepted negative. \\
\hline & $6-9 \mathrm{~mm} *$ & Could be related to non-tuberculous mycobacteria \\
\hline & 10 mm ve üzeri & Accepted positive. \\
\hline \multicolumn{2}{|l|}{ In immunosuppressed persons** } & $5 \mathrm{~mm}$ and over is accepted positive. \\
\hline \multicolumn{3}{|c|}{$\begin{array}{l}\text { BCG: Bacille Calmette-Guerin vaccination, TDM: Non-tuberculous mycobacteria. } \\
\text { * Since it is possible in adults for the immune response to diminish in intensity, the test is repeated within 1-4 weeks in persons with a TST response of } 1-14 \mathrm{~mm} \text { with BCG vac- } \\
\text { cination and 1-9 mm without BCG vaccination, and the value is evaluated according to the table. This practice referred to as the booster effect is not used in the examination } \\
\text { of people in contact. } \\
\text { ** Immunosuppressed persons are those with HIV positivity, AIDS, chronic renal failure, high dose corticosteroid patients (high dose is considered as daily steroid doses } \\
\text { equivalent to } 15 \mathrm{mg} \text { and higher prednizone doses for 2-4 weeks) and other conditions requiring immunosuppressant treatment, and those with reticuloendothelial system } \\
\text { malignancy. }\end{array}$} \\
\hline
\end{tabular}

Provided that BCG vaccination has not been administered in between, at least $6 \mathrm{~mm}$ increase in TST in the last two years and becoming positive or a single $10 \mathrm{~mm}$ increase in TST is defined as TST conversion, and PPD test is considered positive.

Repeated tuberculin tests do not affect active or latent tuberculosis infection process. IGRT is preferred in individuals who has received Bacille Calmette-Guerin (BCG) vaccination rather than the tuberculin test. However, the possibility of uncertain results in children aged under 5 years and in immunosuppressed patients is high, and meticulous evaluation should be made. It is recommended in developed countries that IGRT be performed in individuals aged 5 and over and tuberculin skin test as an alternative. In children under the age of 5 years, vice versa is recommended. If IGRT is to be performed in a patient in whom PPD test has already been done, then it should be carried out within the following three days of PPD test.

\section{References}

1. American Academy of Pediatrics. [Tuberculosis.] In: Kimberlin DW, Brady MT, Jackson MA, Long SS, eds. Red Book: 2018 Report of the Committee on Infectious Diseases. $31^{\text {st }}$ ed. Itasca, IL: American Academy of Pediatrics; 2018:829-53. [CrossRef] 
2. Handbook of Child and Adolescent Tuberculosis. Starke JR, Donald PR (editors). $1^{\text {st }}$ ed. Oxford University Press, NY, 2016, USA. [CrossRef]

3. T.C. Sağlık Bakanlığı Halk Sağlığı Genel Müdürlüğü Tüberküloz Dairesi Başkanlığı Tüberküloz Tanı ve Tedavi Rehberi. Doç. Dr. Fatih Kara (editör). Başak Matbaacılık, 2. Baskı. Sağlık Bakanlığı Yayın No: 1129. Ankara, 2019. [CrossRef]
4. Poeta P, Silva V, Guedes A, Eduardo Pereira J, Cláudia Coelho A, Igrejas $G$. Tuberculosis in the $21^{\text {th }}$ century: Current status of diagnostic methods. Exp Lung Res. 2018 Sep;44(7):352-360. [CrossRef]

5. Mantoux Tuberculin Skin Test DVD Transcript and Facilitator Guide. US Department Of Health And Human Services, Centers for Disease Control and Prevention, CDC. November 2013. https://www.cdc.gov/tb/ education/mantoux/pdf/mantoux.pdf. [CrossRef] 